\title{
Transatlantica
}

Revue d'études américaines. American Studies Journal

\section{Class, Race and American Labor}

Some Consideration on Nelson Lichtenstein's State of the Union

\section{Catherine Collomp}

\section{OpenEdition}

Journals

Édition électronique

URL : http://journals.openedition.org/transatlantica/533

DOI : $10.4000 /$ transatlantica.533

ISSN : $1765-2766$

Éditeur

AFEA

Référence électronique

Catherine Collomp, «Class, Race and American Labor », Transatlantica [En ligne], 1 | 2003, mis en ligne le 23 mars 2006, consulté le 29 avril 2021. URL : http://journals.openedition.org/transatlantica/533 ; DOI : https://doi.org/10.4000/transatlantica.533

Ce document a été généré automatiquement le 29 avril 2021

\section{(c) (i)}

Transatlantica - Revue d'études américaines est mis à disposition selon les termes de la licence Creative Commons Attribution - Pas d'Utilisation Commerciale - Pas de Modification 4.0 International. 


\title{
Class, Race and American Labor
}

\author{
Some Consideration on Nelson Lichtenstein's State of the Union
}

\section{Catherine Collomp}

1 Labor history in the United States is well-chartered territory. It is the object of countless scholarly books, appears in many college and university curricula and it is the subject of on-going revisions and debates. Although labor history has always implied a form of at least implicit social commitment, it has been commented upon and written about as abundantly as other aspects of social history and often with more stamina or vindication. Nineteenth and early twentieth-century working class formation, unionization, and institutional labor organizations, as well as labor politics, strikes and militancy have been studied, commented upon and been the object of sharp discussions.

2 Yet, as we are now in the $21^{\text {st }}$ century, it appears that our knowledge of the second half of the $20^{\text {th }}$ century is not established on such firm ground as is the case for earlier periods. Such concepts as class, working class, workers, unions, have disappeared from the current vocabulary or acquired new meanings. This is not simply the effect of post-modernism, but a sign of what Nelson Lichtenstein calls the "eclipse of the labor question."

3 Familiar explanations of current events on the labor scene fade into insignificance, shift into other categories as de-industrialization has completely changed the structure of the work force and consequently the role and scope of labor unions.

4 In addition, the decline of the organized labor movement itself contributes to discrediting scholarly interest in labor history as a field of inquiry. In a short span of time, towards the end of the 1980 's, labor historians were struck by the disquieting feeling that there is less at stake politically, and also less scholarly interest in studying labor history than there was in the three previous decades. Was it a "ripple effect" of the collapse of the left in all Western societies and of the absence of credible alternatives to the capitalist order or to capitalist societies as they exist today? History is surely about things past, but as many historians have argued, this past is only interesting inasmuch as it is relevant to the present, or can be revisited with contemporary sensitivities. In State of the Union, Nelson Lichtenstein does much to bring 
the question to the fore in its many crucial aspects. His belief that labor has a "unique and transcendent function [...] designed to micromanage the labor market, both inside the workplace and out" (18) stimulates our questions and revives our hopes that the labor question is not out of place in the modern world.

Starting from the firm ground which Nelson Lichtenstein himself contributed to establish of New Deal and World War II labor history, State of the Union provides a new synthesis on the evolution of the American labor movement since World War II (in spite of its subtitle A Century of American Labor, the book is more about the second half of the century than the first).

6 It spans over 5 decades of US labor, political and intellectual history. The scope is wide and the purpose at least twofold. Lichtenstein explains the causes of labor's institutional demise and, more importantly, he emphasizes that, for the sake of the workers, and for American social progress as a whole, unionization is just as necessary as it was at the beginning of the century. This book is therefore predicated, as the author underlines, on the idea that "a larger, more powerful, and more democratic trade-union movement is essential to any progressive reso lution of the contemporary stalemate that structures social politics in the United States" (17). Lichtenstein does not accept the widespread notion that unionization is no longer in the order of the day: wages have declined, arbitrariness reigns supreme, work shifts are long, part time is imposed not chosen, absence of job security prevails in many sectors and especially in the most dynamic ones where jobs are created. The point is made at the outset of the book: "90\% of all private sector workers in the United States are employed under at-will doctrines. [....] The rights of workers as workers, and especially as workers acting in an autonomous, collective fashion, have moved into the shadows. The law, the managerial ethos, the opinion-forming pundits, indeed many workers themselves, have marginalized and ridiculed the idea that democratic norms should govern the workplace" (3).

7 Many explanations have been given for the decline of unionization and unionism. These reasons generally belong to three sets of arguments. They first have sprung from a criticism of the labor movement itself, making it responsible for its inadequacy to the present situation. Much New Left criticism on the failing AFL-CIO leadership in the 1960's, George Meany and his conservative views, has been expressed for long. Paul Buhle's recent book, Taking Care of Business: Samuel Gompers, George Meany, Lane Kirkland and the Tragedy of American Labor (New York, 1999) indicates that from its inception the US labor movement has been plagued by conservative leaders. But that in itself brings us back to the classic question: why is that so? And why have not more radical and open movements of the type of the Knights of Labor, the IWW or the early CIO taken a steadfast hold in the American context?

8 The second set of explanations refers to the economic environment: the changing structure of the economy from the 1960's to the present. De-industrialization, international competition, the rise of a service economy where more than four-fifths of the work force is employed now, the disappearance of the large factories and of a skilled and semi-skilled labor force of operatives which was the basis of union strength, are parts of the explanation.

9 Yet the inability of labor organizations to appeal to white collar workers, and to organize sales and service workers (banks, insurance companies, hotels, restaurants, medical care) is partly a direct consequence of the first problem: the AFL-CIO's absence 
of vision, imagination and radicalism and its snug bureaucracy since the 1950's and 60 's. It has now become practically impossible to organize new locals, let alone new unions. Workers, often employed on a part time basis, and in small units, are rarely likely to risk their jobs for the benefits of a union after years of litigation. Not to mention the legal constraints of the Wagner Act ill-adapted to today's workforce.

Another cause of labor's decline is ascribed to the political culture and managerial prerogatives of American employers: US managers' aggressive tactics to get rid of the unions, or avoid them when none exist, have become highly sophisticated to circumvent labor laws. As Lichtenstein puts it: "The most exceptional character of US labor/management relations is the hostility managers have shown toward the regulatory state and virtually all systems of worker representation" (105). And of course the workers' reluctance to unionize is understandable when the risk incurred for them is that of losing their jobs. American employers' visceral opposition to unionization is not new. It was even fiercer, less subtle, a hundred years ago, and legally so. What now appears is that the New Deal parenthesis (1935-75), which also partly corresponded to the 30 years of a glorious economy, had caused us to forget the employers' historic opposition to labor rights, or had created the illusion that it could be overcome.

11 Nelson Lichtenstein explores these related factors, not successively, but together, seeking to establish the genealogy of the present legal situation through the many stages when laws were enacted, jurisprudence created or modified. The thread through these chapters is legal history. In this respect NL's book has much to do with a line of the school of new labor legal history that includes David Montgomery's Citizen Worker, The Experience of Workers in the United States with Democracy and the Free Market during the XIxth Century (Cambridge, 1993) and other studies more directly related to studying state/labor relations such as Christopher Tomlins (The State and the Unions, New York, 1985) and Melvyn Dubofsky (The State and Labor in Modern America, Chapel Hill, 1994).

12 To state the case clearly, and dramatically, Nelson Lichtenstein offers a fourth set of explanations. He establishes the contradistinction between the workers' collective rights and the ascendancy of individual rights through the litigation of discrimination cases since the 1960's and the Affirmative Action programs. Thus race enters the picture, not so much by reference to the divisive power of racism in the unions or the workplace, but because the nation at large, and employers in particular, are now responding to the demand for racial equality while they are opposed to union recognition and a union's right to establish democracy in the work place.

13 Race and class have always had an antagonistic relation in US social history. That vicious relation has recently been re-emphasized by the crop of "whiteness studies" that have appeared in the last ten years (in the wake of David Roediger's Wages of Whiteness, London, 1991) pointing to the construction of racial identity among white workers and the benefits derived from that consciousness. Lichtenstein's perspective, of course, does not ignore that, but he looks at it from the view point of the new forms of rights consciousness as they have developed since the Civil Rights Act of 1964 and its implementation in the workplace and in all aspects of the public sphere. He maintains that individual workers' rights may easily be vindicated, but not the collective rights of workers-even, and perhaps especially, when they offer a united multiracial front. The employers' legal and economic powers can defeat unionization by way of the old trick of satisfying individual demands of equal treatment thus downgrading the economic 
status of the workers as a collective group and depriving them of empowerment. Lichtenstein brilliantly explains that Affirmative Action has become the most publicized social agenda in the workplace, public or private. Employers' commitment to "Equal Employment Opportunity" for all workers regardless of race, color, sex, religion, national origin, age, or marital status is the rule of the land in labor management. At the same time, insecurity in the workplace has also become the rule of the land and the basis of the new economy.

Indeed US law and society now recognize ethnicity, race, and gender ascription in an unprecedented and favorable manner, thus leading to identity politics and claims that preempt or precede other forms of collective action. But one problem with that interpretation is that of causality. Is it because of the favorable response that anti-discrimination suits have obtained in the courts that the union movement does not keep its hold? Surely not. And the exception given in State of the Union (181-186) of the high degree of unionization among black workers in the public services is proof to the contrary. When unions are not attacked they may flourish, especially if they also fight for racial equality. And figures prove that African-Americans are more likely to be union members than white workers (respectively $25.4 \%, 17.7 \%$ according to the 1989 Statistical. Abstract of the US, for instance). The simple factor of their more massive presence in the working class or lower middle class explains the imbalance.

The articulation between race (or ethnicity and gender) has immense and complexly related variables. It deals with human agency, labor politics, culture and indeed employers, but also with the state, justice, the law and the courts. The problem is the relation between these elements. I would perhaps historicize the interplay between race and class, as aspects of social experience, differently from Lichtenstein's interpretation which emphasizes the 1960's as the moment when individual (anti-discrimination) rights started overcoming collective rights.

16 The nexus of relations between race, class and empowerment has a long history which, until the advent of the CIO, was predominantly one of exclusion for women and non-white workers and therefore a cause for fragility in the labor movement. The Wagner Act, the CIO, and the full employment generated by World War II, reversed that situation. Possibilities for the existence of a powerful labor and inter-racial movement was already at stake in the 1940 's, at the apex of labor's power. But it was immediately attacked by the employers' indomitable resistance which led to the 1947 Taft-Hartley Act and to later acts to curb labor (Landrum Griffin). It is therefore no coïncidence that the Civil rights legislation was belatedly enacted in 1964, that is after labor had been dealt the most severe blows. Not only blows to its regular functioning in the work place (strike regultation, right to work clauses, employers' right to campaign against unionization, stipulated in the Taft Hartley Act). But also, in the context of the Cold War, the most definitive attacks were dealt against labor's radical left, the Communist Party particularly. Only after the labor movement had been deprived of its most radical contenders and able organizers, did the state, through the US Supreme court's judicial activism, began to dismantle segregation. Desegregation was a major achievement, but it operated within the tamed polity of the Cold war era. It is only then that the Warren Court formulated the Brown v. Topeka Board of Education decision (1954), later to be followed by the 1964 Act to more fully eradicate segregation. This was a time when the labor movement seemed economically strong and reunited within the AFL-CIO, but whose political clout, beyond support to the Democratic party, had been eliminated and 
had led to a "pluralist society," that is one where unions are tolerated as long as the economy can support their claims.

Thus if I agree with Lichtenstein that an immense shift in power relations took place in the 1960's and 70's, I think the roots of labor's decline had already been at play since the late 1940's. And the ascendancy of individual rights can be seen as a consequence of the stagnation and decline of labor unionism. In the 1960's, simultaneously the old industrial order began to crumble (inflation, automation, de-industrialization, international competition), and individual rights, the corner stone of American constitutionalism, were given a new recognition by elimination of all discriminatory factors that maintained racial minorities in a form of second class citizenship. The question as to why the labor movement was not able to join forces with the Civil Rights movement to create a broad social and political coalition for social justice lay in these historical precedents. Labor had already become too conservative and too much on the defensive to seize the objective benefit of an alliance with the progressive forces of the Civil Rights movement. These, in addition, were most active and successful in the South where labor was constitutionally weak. And, in the North and West, the failure of the economy to match economic equality with civic equality soon became manifest with the ghetto riots.

18 Several chronologies that reinforce the contemporary shift in power relations are intertwined here. The US Supreme Court's intervention in the realm of individual rights is relatively recent in American constitutional history. It is certainly very new when compared to the right of contracts by which employers have always been free to hire or fire at will. It is only in the $20^{\text {th }}$ century (Gitlow v. New York, 1925) when the SC started to take up the defense of individual rights and only after the 1937 crisis in the court, and the decline of MacCarthysim, that the court was now able to address the problem significantly. If historian Eric Foner has called the Reconstruction an "unfinished revolution," (Reconstruction, America's Unfinished Revolution, New York, 1988) we may suggest that as long as individual rights were not fully equally established the constitutionality of these rights also remained unfinished, that may be what is still at play now.

The question of the primacy of labor's ability to subsume racial antagonism seems to be taken for granted in Lichtenstein's work. And indeed in theory it should be. But most historians of the African-American experience point out to persisting inequalities and hostility. Bruce Nelson's study of steelworkers in the post World War II era (Divided We Stand: American Workers and the Struggle for Black Equality, Princeton, 2001) has shown the inability of the Steel Workers' Union (USWA) to establish equal seniority rights between white and black workers well into the 1960's and 70's, that is when work began to disappear and the union to decline. Even through these decades the rate of unemployment was twice as high among black workers as among whites. Thomas Sugrue (The Origins of the Urban Crisis, Race and Inequality in Post War Detroit, Princeton, 1996) has similar examples for Detroit and the formation of a jobless ghettoized proletariat. And the work of William Julius Wilson (The Truly Disadvantaged: The Inner City, the Underclass and Public Policy, Chicago,1987; When Work Disappears: The World of the New Urban Poor, New York, 1996) has confirmed the persistence of this phenomenon. Race Matters, as Cornel West has suggested (Boston, 1993), and by race, he means the social construction of race on the two sides of inter-racial relations. The subject of race as a shared culture, grounded in religion, a common past and experience, which leads 
to strongly articulated community reactions and today's assertion of equal rights, is not really addressed in these pages.

To my knowledge (limited to the study of the late $19^{\text {th }}$ and early $20^{\text {th }}$ centuries), unionism never was a primary form of organization in the American working class. It only came into existence when it coalesced with other forms of social organization. These were primarily local and ethnic in the context of high immigration rates (and that is still the case today), but also political or religious. The resources for welfare were rooted in ethnic or religious associations and fraternal orders. For instance, the highest degree of organization at the turn of the century was among Jewish workers in the garment trades, it sprang from a common linguistic, cultural, political (socialist) and religious heritage which became a model for the most modern forms of unionization achieved in the 1930's. Unionization also took hold when its structural mode of organization adequately matched the most dynamic forms of industrial production. Trade-unionism among craftsmen in the building trades, for instance, resulted from the fact that they were employed in small units relying on highly skilled workers who thus had leverage on their employers. The success of the CIO, to take another example, lay in its adequacy with the environment of mass production in large factories. But what are the economic structures of production today when de-localization and de-industrialization have transformed the economy? And when the possibilities of unionization for clerical and service workers are practically inhibited by the law with the exception of the public sector?

The situation today may be compared to that of the early $20^{\text {th }}$ century, with the important exception that the local and federal state, as well as large companies, have become the providers of welfare systems, however fragmentary and incomplete these may be. Anti-union employers have seen their advantage in providing insurance benefits in exchange for unionization thus at the same time defeating any universal welfare system which would have created a real counterweight to precariousness. The crucial debate today is that of universality of welfare or of more uniform wage and pay scales. Can any comparison be drawn with the French situation? France has an even lower level of unionization than the United States. Yet its collective bargaining system, also more fragile in today's context, is not limited to actually unionized workers but is extended to all workers in the same sector. The case here is one of centralization and much greater state intervention than the United States would accept, an entirely foreign concept to the American political culture and all the more unlikely to develop in the context of economic liberalism in the US today.

By way of conclusion one may wonder if the heightened awareness of rights, whose effects are so thoroughly and convincingly analyzed in these pages, is only a phase of social relations, which when completed, as David Hollinger has hoped it will be (Post Ethnic America: Beyond Multiculturalism, New York, 1995), would lead to a more fully egalitarian and universal citizenry, and therefore to a more stable ground base for a workers' movement? The present situation in the United States and the globalization of national economies in modern capitalism do not lead to unmitigated optimism for the reconstruction of a broad union movement. 